\title{
Like Butter Scraped Over Too Much Bread. The North Sea, Skagerrak and Kattegat—an Overlooked Region in Maritime Defence and Security?
}

\author{
Niklas Granbolm
}

\section{Introduction and aim - an emerging naval defence and security problem}

Among the clearly observable global geostrategic shifts towards a less predictable security environment, discussion on the naval and maritime effects of this on Northern Europe is also on the increase. ${ }^{1}$ One of the focal points is on the strategic development in the North Atlantic, the High North and the Arctic. ${ }^{2}$ The follow-on effects in the seas adjacent to the North Atlantic, The North Sea, Skagerrak and Kattegat-henceforth the Western Seas-has so far received less attention. Maritime strategic trends there are affecting the whole of the Nordic region as well as the nations around the Baltic Sea and the North Sea, including Russia. The region is key to much of the trends as regards the naval and maritime domain for Northern Europe in several ways.

The aim of this chapter is to analyse the waters approaching and connecting with the Baltic Sea and the North Atlantic from the perspective of naval and maritime security. The functioning of the Sea-lines of Communication (SloCs) is vital to the economic life of all the Nordic and Baltic Sea nations. Seaborne trade in and out of the region, as well as within it, is intense and increasing. From 2012 to 2019, transport work (ton-miles) for all categories of civilian cargo shipping through the North Sea increased by $12.2 \%$, through Kattegat by $23.9 \%$ and through Skagerrak by $22.3 \% .^{3}$

1 I would like to extend my gratitude to several friends and colleagues, within and outside FOI, who contributed with insightful and constructive comments in various ways during the process of writing. You know who you are. Any remaining weaknesses remain entirely my own responsibility.

2 Magnus Nordenman, The New Battle for the Atlantic. Emerging Naval Competition with Russia in the Far North. (Maryland: Naval Institute Press, 2019).

3 Data compiled and supplied by Mr Torbjörn Rydbergh. Copyright (C), Marine Benchmark Gothenburg AB, 2021. All Rights Reserved, Source data: IHS Markit \& Marine Benchmark. January 19, 2021. 
The highly IT-dependent nations rely heavily on telecommunications cables on the seabed. Pipelines for oil and natural gas, cables for large-scale offshore wind power hubs as well as electric transmission cables criss-cross the seabed, which further increases the importance of these seas. The region is an example of how the role of the sea itself is changing: energy generation, telecommunication as well as the region's intra-regional connections with the world beyond can be added to its classical role as a transportation route and as a base for the extraction of biological and fossil resources.

Maritime defence and security aspects are playing an increasingly central part in a period when both high-end conflicts and a spectrum of greyzone confrontations are emerging. The aim of this chapter is thus twofold:

- To describe and analyse the problem of emerging maritime strategic challenges in the North Sea, Skagerrak and Kattegat.

- To discuss and indicate solutions to the problem. With what means and with which methods could the region be defended over a broad spectrum of conflicts?

The perspective is that of an analysis of the region mainly with a Swedish and regional outlook. If not otherwise indicated, the time perspective is ten years into the future. 
Ports and water depths in The North Sea, Skagerrak and Kattegat. Map by FOI.

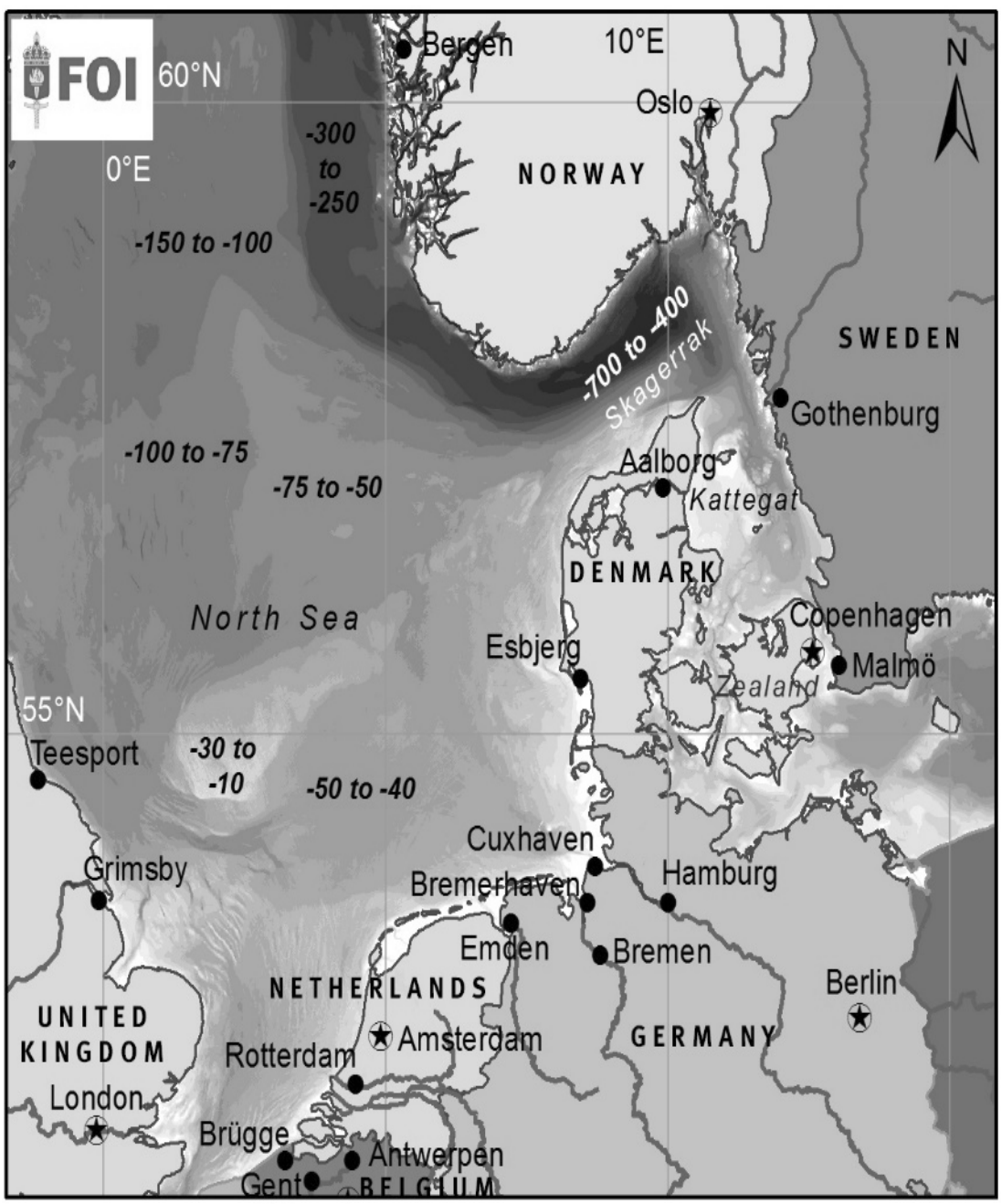

The North Sea, Skagerrak and Kattegat from a maritime and oceanographic perspective

Oceanographically, the Western Seas present highly varied conditions. The area from shallow waters of Dogger Bank in the North Sea with its rich fishing waters to the deep waters of the Norwegian trench with depths of 
up to 700 metres complicates the laying of pipelines. The narrow straits of The Belt (Store Belt) and the Sound (Öresund), present challenging conditions for shipping. Three archipelagos are also part of the picture: the Frisian Islands, the Gothenburg archipelago and Heligoland. Sea conditions are often rough and varied. Tidal waters with strong currents at times also form part of the nautical conditions.

The Western Seas are central to all nations in the adjacent Baltic Sea region. With its population of around 100 million and vibrant and modern economies, seaborne trade has increased substantially in the past few decades. At any given moment, around 2,000 ships operate in the Baltic Sea. The region of western Scandinavia, Oslo and the adjacent counties Bohuslän, the city of Gothenburg, Halland and Skane on the Swedish west coast, is in itself a mega-region, generating substantial parts of Norwegian and Swedish GDP. ${ }^{4}$ The waterways connect the Western Seas and the Baltic Sea with the North Atlantic and the world oceans.

Several of Europe's major ports in the supply much of the imports for Northern Europe and beyond, plus the exports for a just-in-time dependent region. Along with other ports, they uphold a network vital to economic life, prosperity and security.

With the end of the Cold War, far-reaching retrenchment of navies and military forces followed. 5 The shifting priorities for maritime security operations also had long-term perceptual and conceptual effects on European navies. They refocused and prioritised Maritime Security Operations (MSO), while high-end operations were mostly relegated to second or third priority. Combined with extensive retrenchment, officers and planners were not able to transfer their expertise to the next generation. In several Western navies, this shift of priorities led to a loss of tactical, operational and strategic knowledge.

With deteriorating strategic trends, the capability gap has exposed security and defence problems. With attempts to address the problem of defending SloCs leading to the west coast and into the Baltic Sea in conditions of grey-zone as well as high-end warfare, and developments in the region as a route for energy- and telecommunications, the Western Seas now

4 Lars Wedin and Odd Werin, Var marin för ett tryggt Sverige och ett starkt Europa. Marin Strategi 2030. (Our Navy for a Secure Sweden and a Strong Europe. Naval Strategy for 2030). (Stockholm: Royal Swedish Academy of War Sciences, 2020), 32.

5 Jeremy Stöhs. Decline of European Naval Forces. Challenges to Sea Power in an Age of Fiscal Austerity and Political uncertainty. (Maryland: Naval Institute Press, 2018). 
qualify as congested, cluttered, contested, connected and constrained-a maritime C5-region. ${ }^{6}$

\section{The Western Seas-maritime-strategic developments and capabilities}

This section discusses the problems of naval strategic trends versus available resources with brief overviews of the relevant navies in and outside the region.

The aforementioned regional confrontation stems not least from the build-up and partly new profile of the Russian navy, supported by updated naval doctrines. ${ }^{7}$ The Russian Northern and Baltic fleets now operate with more self-confidence, with improved coordination, growing in capability and numbers, and with a dynamic, flexible, offensive and at times aggressive stance in the region. ${ }^{8}$ In addition, China is emerging as a new naval global strategic actor. With rapidly increasing naval capabilities, China already intermittently operates in the region. It seems likely that its activities in the region will increasingly become a part of the operational pattern in the coming decade.

The globally dominant US Navy sees a difficult road ahead with several major and simultaneous long-term strategic challenges. ${ }^{9}$ From its core strategic naval priority with China in the Pacific region and a more assertive Russia, a demand for presence and operations in the Arctic as well as an increasingly demanding operational environment in the North Atlantic have emerged. With the reinstatement of the US Navy $2^{\text {nd }}$ Fleet in 2018, the issue of resourcing has come into focus. Balancing naval assets for operations in the main US theatres will be complicated, not least regarding their allocation to this European region. Added to the mix are technological developments, their integration and possible quantum leaps with po-

6 United Kingdom Ministry of Defence. DCDC, Strategic Trends Programme. Future Operating Environment 2035. (First edition, 2015). 44.

7 Jonas Kjellén. The Russian Baltic Fleet - Organisation and Role Within the Armed Forces in 2020. (Stockholm, February 2021. FOI-R--5119-SE). Douglas Barrie and James Hackett (eds.). Russia's Military Modernisation. An Assessment. (London: International Institute for Strategic Studies, 2020). 91-116.

8 The Economist. Naval strategy. Northern Fights. (London: 16 May 2020). 19.

9 United States Department of the Navy. Advantage at Sea. Prevailing with Integrated All-Domain Naval Power. December 2020. 
tentially far-reaching implications for structure, concepts and ship design, with budgetary challenges to boot. ${ }^{10}$

For the Royal Navy, with its long tradition of operations in these waters, including the Baltic Sea, the Western Seas form one part of the demands placed upon its naval forces. The link to a post-Brexit "Global Britain”, in part a search for a new role, also implies an increased call for more naval capabilities in the North Atlantic, the High North and elsewhere. ${ }^{11}$ Numbers will matter-operational demands and technological shifts mean that this circle will not be easy to square. How many resources will be available for the Western Seas therefore remains an open question. For the Royal Navy, available resources for the global challenges that are too thinly spread mean that setting priorities will be complicated. Recently announced investments in new surface combatants will go some way to addressing this, but will take time to have an effect. Similarly to other navies, technological challenges abound. On balance, there does not seem to be a short to medium-term solution to the Royal Navy's resource-demand problems.

The German Deutsche Marine has seen a turnaround in recent years. Its previous high operational priorities on Maritime Security Operations (MSO) with a global scope have shifted to a primary focus on the Baltic Sea and the North Atlantic. To support Baltic Sea operations, Germany has set up a Baltic Maritime Component Command (BMCC) in Rostock with the aim of coordinating naval operations from there.

Funding has also increased. This has enabled investments in a second batch of five K 130 Braunschweig-class corvettes in addition to the five already operational. The readiness of the submarine arm has increased from a very low level and the Seebatallion is transforming into an amphibious corps with the support of the Dutch Korps Mariniers. When the replacement of existing maritime patrol aircraft is due, the naval air component may also be renewed. In order to increase retention rates, wages for sailors have been raised.

Further modernisation of the fleet is also underway with the new MultiPurpose Combat Ship (Mehrzweckkampfschiff 180), MKS 180, and the recently renamed Frigate class 126 . The class is designed for intensive usabili-

10 United States Navy, Chief of Naval Operations. CNO NAVPLAN 2021. January 2021.

11 Chief of Defence Staff General Nick Carter describes one of the tasks for the British Armed forces as holding Russian forces "at risk" in the High North, The Baltic Sea and the Black Sea. Nick Carter. Annual Chief of the Defence Staff Lecture 2020, (Whitehall: Royal United Services Institute, 18 December 2020). 
ty, with a modular design and multi-crew-concept similar to the BadenWürttemberg frigate class. The first of the four in the new 126-class is due for delivery during 2027.

The current federal CDU-SPD coalition government supports this increase in German naval capabilities. The government sees the navy as an important component of the armed forces. From the outside, bureaucratic impediments seem to be slowing the process.

Denmark regards the Royal Danish Navy (RDN) as a national strategic instrument for international influence. Maintaining transatlantic relations with close allies is key in this context, where the RDN plays a central role. ${ }^{12}$ In addition, emerging challenges in the North Atlantic and around Greenland are impacting on strategic priorities. Carrier group-escort tasks with the US Navy and Royal Navy, SloC-defence, sovereignty support of Danish overseas territories and MSOs are high on the priority list. Denmark thus currently places the North Sea, Skagerrak, Kattegat and the Danish Straits lower on its list of operational priorities, and has all but abandoned operations in the Baltic Sea. To meet the need for more capabilities in the North Atlantic, its surface fleet is being upgraded through the re-roling and equipping the flexible support ships (Flexible Stotteskibe) of the Absalon-class to serve as ASW-frigates. Similarly, the Iver Huitfeldtclass is being redeployed as AAW-frigates. These changes are covered in the 2018-2023 agreement on Danish defence development. The RDN is striving to become an Integrated Air and Missile Defence Navy (IAMD). ${ }^{13}$ Added to that picture are shrinking MCM resources, which has implications for international shipping through the Danish Straits. Given the limited funds available and other big-ticket investments, such as the F-35 system for the RDAF, these are ambitious tasks.

The Royal Norwegian Navy (RNoN) has its main operational focus in the High North. The Russian naval and military build-up of the Northern fleet guides much of Norway's naval and military focus, while opening up more scope for Nordic military cooperation. ${ }^{14}$ Over the past two decades, most of Norway's naval and military assets have moved from southern Norway to the north. The end of the Cold War had also led to substantial

12 Johannes Riber. The Royal Danish Navy. How Small States Use Naval Strategy. In Europe, Small Navies and Maritime Security. Balancing Traditional Roles and Emergent Threats in the 21st Century. Eds. Robert McCabe, Deborah Sanders, Ian Speller, (Abingdon, Routledge 2019). 152-167.

13 Edward Lundquist. "Royal Danish Navy becoming a missile defense force by design”. Tidskrift $i$ Sjöväsendet, No. 3/2020.

14 Sverre Diesen. "Én for noen, noen for én”. Norsk Militaert Tidsskrift nr. 4/2020. 
overall retrenchment of the Norwegian armed forces. Few resources-surface combatants and MCM resources-are available for operations in her southern waters.

In December 2020 the Swedish Parliament decided on a five-year defence bill after a long process of political wrangling. ${ }^{15}$ The bill will increase defence spending steeply to about $1.5 \%$ of GDP by 2026, an increase of about $40 \%$. A build-up of the Swedish armed forces began in the wake of Russia's war on the Ukraine from 2014 and continues onwards. This adaption will take time and is seen by many as insufficient.

For the Royal Swedish Navy (RSwN), the 2020 Defence Bill will mean a modest increase in capabilities. A new, more modern and seagoing amphibious corps battalion is returning to Gothenburg, with new and more capable anti-ship missile carrying boats. The number of submarines will increase from four to five, and the first two in a new class of surface combatants will be developed. Existing surface combatants of the Visby-class corvettes will receive a mid-life upgrade and surface-to-air missiles will finally be added. Four older corvettes will get life-extensions with their antiship missile capabilities retained. The land-based anti-ship missile capability is being modernised. Importantly, mobile land-borne and ship-borne logistic capabilities will increase.

The decades-long retrenchment of the Swedish armed forces means that deficiencies in numbers and capabilities are substantial. The $\mathrm{RSwN}$ is no exception, and this will take time and funding to address. The Swedish naval and maritime defence debate has called for a substantial increase in the number of platforms and capabilities, and points out the high average age of platforms. ${ }^{16}$ Accordingly, there will be a fair amount of "expectation management" in explaining the modest increases. ${ }^{17}$ An increased but limited naval presence on the Swedish west coast will follow, but the classic Swedish defence dilemma relating to the allocation of scarce naval resources, either for the west coast or for the Baltic Sea, remains unsolved. Due to the scarcity of platforms and capabilities, Sweden can either be supplied in the west or defended in the east. Assets for MSOs will also remain limited. This is an unenviable situation, both in grey-zone and high-end conflict scenarios. To mitigate the west coast problem, Sweden is seeking

15 Government of Sweden. Regeringens proposition 2020/21:30. Totalförsvaret 202125. Stockholm 14 October 2020.

16 Kungl. Örlogsmannasällskapet. En marin för Sverige (A Navy for Sweden), (Stockholm: Printfabriken, 2018).

17 RADM Ewa Skoog Haslum, Commander of the RSwN. Interview, Stockholm, 2 December 2020. 
enhanced cooperation with Nordic partners, mainly Denmark and Norway. ${ }^{18}$ Moreover, statements in late December in parliament by the minister for defence that "...Sweden will as far as possible, develop joint operational planning with Finland and coordinated planning with Denmark, Norway, the United Kingdom, the United States and Nato" are noteworthy. The limits set by the Swedish Cold War declaratory policy of neutrality are clearly a thing of the past. ${ }^{19}$ There is also a realisation of the inherent flexibility of naval forces - their fungibility-indicating their value in a less predictable strategic climate. ${ }^{20}$

The increases in $\mathrm{RS} w \mathrm{~N}$ capabilities for the next five years will lead to it becoming a more robust organisation. While the writing in the defence bill argues for the importance of the western region as a critical supply route and the need for a more assertive stance on the Swedish west coast, corresponding investments are as yet mostly lacking.

Nato/PfP exercises in Northern Europe have increased substantially, both in number and in complexity since $2014 .{ }^{21}$ Most of the exercises have had a geographic focus in the Baltic Sea region and the High North. Few seem to have taken place in the Western Seas. Strategic sealifts have so far played a small part in logistic support exercises for forces in Europe.

To summarise, naval resources for the Western Seas will remain scarce in the near-term. The North Atlantic and the Arctic Ocean theatres are in focus. Naval and military trends in the Pacific act as an attractor for resources for navies like the US navy, and to an extent for the Royal Navy. The Nordic navies either have their focus elsewhere or are not resourced in relation to emerging trends. Nato has so far prioritised exercises elsewhere than the Western Seas.

$18 \mathrm{Mr}$ Peter Hultqvist, Minister of Defence. Interview, Stockholm, 16 December 2020.

19 Jonas Gummesson. "Försvarsmakten redo hjälpa till med vaccineringen mot covid-19". (The armed forces stand ready to contribute to vaccination against covid-19), Svenska Dagbladet (10 January 2020). 8-9.

20 Dr. Pål Jonson. Chairman of the Defence Committee, Swedish Parliament. Interview, Stockholm, 3 December 2020.

21 Albin Aronsson and Björn Ottosson. Västlig militär övningsverksambet 2014-2019 Anpassning, utveckling och framsteg. (Western Military Exercises 2014-2019-Adjustment, Development, and Progress). (Stockholm: Swedish Defence Research Agency, March 2020), FOI-R-4875-SE. 


\section{Technology—quantum leaps or slowly maturing?}

Naval technologies are developing fast. Some systems are developing more slowly, while others are characterised by quantum leaps that, in a short time, may render much of existing systems outdated. These trends will affect all navies, types of platforms, their design, numbers and systemic structure. Development and operation of high-end naval platforms are capital-intensive. With a life cycle of several decades, deciding on their design and choosing systems in a technologically dynamic time are daunting tasks. Several of the navies discussed here also operate platforms that need replacing within a ten to twenty-year period. How can the development of risky and "future-proof" naval platforms and systems be mitigated? While complexity and dynamic technological trends increase the risk of mistakes, they can also provide opportunities. For naval defence and security in the Western Seas, this also opens up several possible combinations of new and old technologies for systemic effect. The problem of balancing risk-benefit-opportunity is as obvious as it is complicated.

A great number of trends in technology for the naval sector are already available or are about to take significant steps forward. ${ }^{22}$ Among them, maturing networked systems enable different platforms to provide substantially higher threshold capabilities. This can give advance warning when available scarce resources are deployed in both lower-level and high-end conflicts.

Sensors are also developing. For UUVs and USVs, substantially larger grids of connected sensors are becoming available. Combined with improved underwater communications connected with effective networks, these will become a substantial addition to naval operations.

For surface platforms, the trend is towards developing two main types: "thoroughbreds" for high-end conflicts and "workhorses" for sustainable long-term operations and protection of SloCs. In practice, a high-low mix of platforms is underway in many navies, due to their high development costs. A second trend is the increasing coordination between and integration of sea and air power due to the rising cost of platforms driving numbers further down. A third trend points to longer ranges and increasing precision for ship-borne and land-based surface-to-surface missiles, with in-

22 Göran Kindvall and Anna Lindberg (eds.) Militärteknik 2045. Ett underlag till Försvarsmaktens perspektivstudie. (Military Technology 2045. Report for the Armed Forces long-term study). (Stockholm: Swedish Defence Research Agency, November 2020). FOI-R-4985-SE. 181-200. 
flight target data communication being an additional factor in design. In addition, supersonic, possibly also hypersonic, missiles need to be taken into consideration. This points to missiles that are likely to be bigger, which will increase the demand for ships with bigger hulls to accommodate them. A fourth trend is for substantially increased demand for electric power. Ship-borne laser weapons, electromagnetic rail guns (EMRG), High-Power Microwave (HPM) as well as all-electric propulsion will also impact design. The need for ammunition storage, electric power, re-supply, etc. will likely need to be balanced differently. The trend towards fossil-free propulsion is also likely to spill over from civilian shipping into the naval sector.

For the subsurface domain, submarines remain the most advanced and expensive category of platforms and they continue to offer substantial deterrent capabilities. Improved underwater communications are also likely to bring advantages in mine detection and mine clearing. The underwater domain is also benefiting from developments leading to increasingly networked, unmanned, distributed and autonomous concepts. This in turn indicates that platforms with these capabilities will become more common.

The topic of trends in technology is vast and cannot be comprehensively discussed here, but the questions they raise clearly merit further analysis. In what way can fast-developing technological trends be utilised to contribute to solutions to the defence and security problems in the Western Seas? What are the challenges they pose? What technological solutions are available and in what time frames so that deficits in capabilities and numbers can be addressed?

\section{Solutions—systems, combinations and cooperation}

The analysis above points to a number of complicated and complex problems for naval and maritime defence and security in the Western Seas. The main questions for this chapter were:

- To describe and analyse the problem of emerging maritime strategic challenges in the North Sea, Skagerrak and Kattegat.

- To discuss and indicate solutions to the problem. With what means and with which methods could the region be defended over a spectrum of conflicts?

The region is facing a substantial number of challenges as a follow-on effect to global strategic trends. It also seems likely that Russian and proba- 
bly Chinese naval forces will be increasingly active in the region, while the US Navy, the strongest navy with a global reach, has its main focus on the Indo-Pacific region. In a similar manner, regional navies are either overextended, too weak or have their main operational priorities somewhere else. Fast-developing technological trends further add to these challenges.

Expanded and deepened naval cooperation would provide part of a solution in order to make the best use of scarce resources over a spectrum of grey-zone confrontations up to and including armed conflict. The first and most obvious contribution would be to set up or enhance existing cooperative arrangements. Successful models already exist. For the Baltic Sea, Sweden and Finland operate a joint naval task group-the SFNTG—with a high level of tactical integration and with strong support from both countries' capitals. ${ }^{23}$ A similar set-up could be replicated for the Western Seas with contributions from relevant navies.

Nato's existing naval forces and formats could also be considered: the Nato Response Force (NRF) through MARCOM, using Standing Maritime Groups one and two (SNMG $1 \& 2$ ) and the Standing Naval Mine Countermeasures Group one (SNMCMG 1), the Naval Striking and Support Forces NATO (STRIKEFORNATO) and not least the Very High Readiness Joint Task Force (VJTF). Outside Nato, the Joint Expeditionary Force (JEF) and the cooperative format of The Northern Group of nations should also be considered. Possibly, the Nordic Defence Cooperation (NORDEFCO) could be another format to consider.

The trend towards more task group operations and away from singleship operations among Western European navies further points to the advantages of such arrangements. A dedicated task group for the North Sea, Skagerrak and Kattegat (NSKTG) could be set up under a regional arrangement, manned under a time-sharing scheme by the navies in the region, while remaining flexible in content and open to contributions from other nations as required. A CONOPS requirement for such a task group is that it should be able to continuously share tactical and operational intelligence in order to enable timely dispositions. To manage a broader spectrum of tasks-from grey-zone situations up to and including high-end conflict - a high-resolution regional Recognized Maritime Picture (RMP) would be a necessary requirement with relevant coastguard capabilities integrated into the concept.

23 Lee Willett. "The Role of Task Groups in Baltic Security". Tidskrift $i$ Sjöväsendet No.4/2020. 341-345. 
The German Navy could add further capabilities to such a solution. It is likely that the German naval build-up will continue. The Baltic Maritime Component Command (BMCC), primarily focused on the Baltic Sea, could be given the additional task of coordinating regional activities in the Western Seas. Denmark and Norway could contribute with available resources and not least with their regional expertise. The Royal Navy is also a substantial actor in the region. The recently announced investment in naval capabilities will begin to take effect late in this decade.

Lastly, Sweden needs to take a step forward. A continuous naval presence on its west coast is coming from available force levels, with additions in the 2020 Defence bill. ${ }^{24}$ However, this will not suffice. The number of surface combatants and submarines will increase only marginally and from low numbers. The new amphibious unit is a welcome and necessary component. What is urgently needed is an increased MCM-capability and clarity on new capabilities, not least regarding helicopter-borne ASW. The number of surface combatants also needs to increase. Investments in UUVs, UAVs and USVs should also be included.

To optimise decisions on which technologies and systems to invest in, there is a need for a sorting mechanism. To discuss and evaluate new technologies and systems, three factors need to be included: cost, time and operational effect. An expensive system might be difficult to accommodate within limited budgets. How long it takes to develop and integrate a system also matters. Is the need urgent, or is it more of a long-term development programme? Lastly, what operational effect would a new system or technology add to the force structure? These three factors should form part of an iterative process of evaluation that, in turn, needs to be a component in interaction with theoretical and practical circumstances when Sweden is developing a coherent naval and maritime strategy. ${ }^{25}$

$*$

The current situation regarding resources and assets vis-á-vis challenges for the naval and maritime problems in the Western Seas may seem "...like butter scraped over too much bread”. However, a broad set of methods for

24 Interview, RADM Ewa Skoog Haslum, Commander of the RSwN. Stockholm, 2 December 2020.

25 Geoffrey Till. The Accidental Dialectic: The Real World and the Making of Maritime Strategy Since 1945. in Conceptualizing Maritime \& Naval Strategy. Festschrift for Captain Peter M. Swartz, United States Navy (ret.). Sebastian Bruns and Sarandis Papadopoulos (eds.). (Baden-Baden, Germany: 2020). 13-32. 
solutions is available. A combination of technological foresight, intensified multinational dialogue and bilateral and multilateral cooperation to avoid ingrained habits of bureaucratic stove-piping is needed. Not least, increased insight among policymakers is required to grasp the emerging strategic maritime problems in a less predictable world.

\section{Works cited}

Aronsson, Albin and Ottosson, Björn. Västlig militär övningsverksambet 2014-2019. Anpassning, utveckling och framsteg. (Western Military Exercises 2014-2019-Adjustment, Development, and Progress). Stockholm: Swedish Defence Research Agency, March 2020). FOI-R-4875-SE.

Barrie, Douglas and Hackett, James (eds.). Russia's Military Modernisation. An Assessment. London: International Institute for Strategic Studies, 2020.

Carter, Nick. Annual Chief of the Defence Staff Lecture 2020, Whitehall: Royal United Services Institute, 18 December 2020.

Diesen, Sverre. "Én for noen, noen for én". Norsk Militaert Tidsskrift No. 4/2020, 1425.

The Economist. Naval strategy. Northern Fights. London, 16 May 2020: 19.

Government of Sweden. Regeringens proposition 2020/21:30. Totalförsvaret 2021-25. Stockholm, 14 October 2020.

Gummesson, Jonas. "Försvarsmakten redo hjälpa till med vaccineringen mot covid-19". (The armed forces stand ready to contribute to vaccination against covid-19), Svenska Dagbladet. 10 January 2021, 8-9.

Kindvall, Göran and Lindberg, Anna (eds.) Militärteknik 2045. Ett underlag till Försvarsmaktens perspektivstudie. (Military Technology 2045. Report for the Armed Forces long-term study). Stockholm: Swedish Defence Research Agency, November 2020: 181-200. FOI-R-4985-SE.

Kjellén, Jonas. The Russian Baltic Fleet - Organisation and Role Within the Armed Forces in 2020. February 2021. FOI-R--5119--SE.

Kungl. Örlogsmannasällskapet. En marin för Sverige (A Navy for Sweden), Stockholm: Printfabriken, 2018.

Lundquist, Edward. "Royal Danish Navy becoming a missile defense force by design”. Tidskrift i Sjöväsendet, No. 3/2020, 305-309.

Nordenman, Magnus, The New Battle for the Atlantic. Emerging Naval Competition with Russia in the Far North. Maryland: Naval Institute Press, 2019.

Riber, Johannes. The Royal Danish Navy. How Small States Use Naval Strategy. In Europe, Small Navies and Maritime Security. Balancing Traditional Roles and Emergent Threats in the 21st Century, edited by Robert McCabe, Deborah Sanders, Ian Speller. Routledge: Abingdon 2019, 152-167.

Stöhs, Jeremy. Decline of European Naval Forces. Challenges to Sea Power in an Age of Fiscal Austerity and Political uncertainty. Maryland: Naval Institute Press, 2018. 
Rydbergh, Torbjörn. Data set compiled by Marine Benchmark Gothenburg AB, 2021. IHS Markit \& Marine Benchmark. January 19, 2021.

Till, Geoffrey. The Accidental Dialectic: The Real World and the Making of Maritime Strategy Since 1945. In Conceptualizing Maritime \& Naval Strategy. Festschrift for Captain Peter M. Swartz, United States Navy (ret.), edited by Sebastian Bruns and Sarandis Papadopoulos. NOMOS: Baden-Baden 2020, 13-32.

United Kingdom Ministry of Defence. DCDC, Strategic Trends Programme. Future Operating Environment 2035. First edition, 2015, 44.

United States Department of the Navy. Advantage at Sea. Prevailing with Integrated All-Domain Naval Power. December 2020.

United States Navy, Chief of Naval Operations. CNO NAVPLAN 2021. January 2021.

Wedin, Lars and Werin, Odd. Var marin för ett tryggt Sverige och ett starkt Europa. Marin Strategi 2030. (Our Navy for a Secure Sweden and a Strong Europe. Naval Strategy for 2030). Stockholm, Royal Swedish Academy of War Sciences, 2020, 32.

Willett, Lee. "The Role of Task Groups in Baltic Security". Tidskrift i Sjöväsendet No.4/2020, 341-345.

\section{Interviews}

Mr. Peter Hultqvist, Minister of defence. Stockholm, 16 December 2020.

Dr Pål Jonson. Chairperson of the Defence Committee, Swedish Parliament. Stockholm, 3 December 2020.

Mr Torbjörn Rydbergh. Marine Benchmark Gothenburg AB, 2021. January 18-19, 2021.

RADM Ewa Skoog Haslum, Commander of the RSwN. Stockholm, 2 December 2020. 
